\section{Pruritus of polycythaemia vera: a place for pizotifen?}

Generalised pruritus occurs in $25-50 \%$ of cases of polycythaemia vera. Neither the cause nor the most effective treatment has been established. A relation with iron deficiency has been suggested and relief after iron treatment recorded.' Cholestyramine has been reported to have an antipruritic action in polycythaemia vera, which might imply an association with raised concentrations of conjugated bile acids. ${ }^{2}$ While generally thought to be related to disease activity, the pruritus also appears to be associated with raised histamine concentrations in blood and urine ${ }^{3}$ Conventional antihistamines are seldom successful, however, and the place for cimetidine treatment is not yet clear $^{4}$; despite this, the reported beneficial response to cyproheptadine has been attributed to its potent antihistamine effect. ${ }^{3}$

The complete relief of pruritus after the introduction of pizotifen prescribed for migraine prophylaxis and its relapse after withdrawal of the drug in a woman with active polycythaemia vera led us to examine the effect of pizotifen on the pruritus of polycythaemia vera. The association of iron deficiency, disease control (as judged by Coulter values), and concentrations of conjugated bile acids with the pruritus was also examined.

\section{Patients, methods, and results}

Fifteen patients with polycythaemia vera completed prepared questionnaires. These questionnaires contained 10 questions concerning possible symptomatology, including the presence or absence of generalised pruritus but not specifically calling attention to this symptom. Those patients who identified pruritus as a symptom received 10-day courses of both the active drug and placebo with an intervening four-day wash-out period. In an attempt to reduce the placebo response neither the symptom qualifying for selection nor any possible antipruritic effect of pizotifen was explained. Pizotifen tablets (Sanomigran, containing $0.5 \mathrm{mg}$ of pizotifen) and identical placebos were provided by Wander Pharmaceuticals. The dosage used was the starting dosage recommended for migraine prophylaxis-namely, $0.5 \mathrm{mg}$ thrice daily. Further questionnaires were completed during the wash-out period and at the conclusion of the trial. Side effects were recorded.

The table records the results of investigations performed on all 15 patients. Concentrations of conjugated bile acids were measured by the Becton Dickinson solid-phase radioimmunoassay kit. Six of the nine patients with pruritus obtained from good to complete relief with pizotifen. Five patients complained of drowsiness when they started the active agent, but this settled in all but one (case 8 ).

Results of investigations performed on the 15 patients with polycythaemia vera (pruritus was present in only cases 7-15)

\begin{tabular}{|c|c|c|c|c|c|c|c|}
\hline $\begin{array}{l}\text { Case } \\
\text { No }\end{array}$ & Sex & $\underset{(\mathbf{g} / \mathrm{dl})}{\text { Haemoglobin }}$ & $\begin{array}{c}\text { Packed } \\
\text { cell } \\
\text { volume } \\
(\text { "., }\end{array}$ & $\begin{array}{l}\text { Red cell } \\
\text { count } \\
\left(\times 10^{4} / 1\right)\end{array}$ & $\underset{(\mu \mathbf{g} / 1)}{\text { Ferritin* }}$ & $\begin{array}{c}\text { Conjugated } \\
\text { bile } \\
\text { acidst仿市 } \\
(\mu \mathrm{mol} / \mathrm{l})\end{array}$ & $\begin{array}{l}\text { Response to } \\
\text { pizotifen }\end{array}$ \\
\hline $\begin{array}{r}1 \\
2 \\
3 \\
4 \\
5 \\
6 \\
7 \\
8 \\
9 \\
10 \\
11 \\
12 \\
13 \\
14 \\
15\end{array}$ & $\begin{array}{l}M \\
F \\
M \\
M \\
M \\
M \\
M \\
M \\
M \\
F \\
M \\
M \\
F \\
F \\
M \\
M\end{array}$ & $\begin{array}{l}14.6 \\
14.3 \\
14.0 \\
16.5 \\
15.7 \\
12.1 \\
17.6 \\
16.5 \\
16.8 \\
17.5 \\
13.7 \\
11.8 \\
13.4 \\
14.1 \\
19.1\end{array}$ & $\begin{array}{l}45 \\
41 \\
43 \\
51 \\
51 \\
36 \\
52 \\
50 \\
50 \\
54 \\
45 \\
35 \\
39 \\
45 \\
56\end{array}$ & $\begin{array}{l}5 \cdot 5 \\
4 \cdot 5 \\
6 \cdot 3 \\
5 \cdot 5 \\
6 \cdot 7 \\
4 \cdot 0 \\
6 \cdot 2 \\
6 \cdot 1 \\
5.4 \\
7 \cdot 0 \\
6 \cdot 8 \\
3.1 \\
4.5 \\
7 \cdot 0 \\
6.6\end{array}$ & $\begin{array}{c}53 \\
130 \\
2.5 \\
59 \\
2 \cdot 2 \\
260 \\
3.5 \\
9.8 \\
44 \\
4.8 \\
3.6 \\
90 \\
51 \\
2.8 \\
8.0\end{array}$ & $\begin{array}{c}4 \cdot 3 \\
1 \cdot 7 \\
4 \cdot 4 \\
2 \cdot 6 \\
14 \\
10 \\
3 \cdot 7 \\
8 \cdot 6 \\
4 \cdot 4 \\
5 \cdot 1 \\
3 \cdot 4 \\
4.5 \\
3 \cdot 3 \\
1.5 \\
4.9\end{array}$ & $\begin{array}{l}\text { Good } \\
\text { Nil } \\
\text { Complete } \\
\text { Nil } \\
\text { Good } \\
\text { Good } \\
\text { Complete } \\
\text { Good } \\
\text { Nil }\end{array}$ \\
\hline
\end{tabular}

Normal ranges: ${ }^{*}$ ferritin $15-300 \mu \mathrm{g} / \mathrm{l} ;$ +conjugated bile acids $0-6 \mu \mathrm{mol} / 1$.

Conversion: SI to traditional units-Conjugated bile acids: $1 \mu \mathrm{mol} / 1 \approx 0.5 \mathrm{mg} / 1$

\section{Comment}

Pizotifen is widely prescribed for migraine prophylaxis and possesses potent antihistamine and antiserotonin effects. It is well tolerated. Drowsiness and increased appetite often occur during treatment, but in most cases these usually prove mild and transient. ${ }^{5}$

Pruritus and its severity is a particularly subjective phenomenon; the trial was designed to reduce the placebo response, which in other antipruritic trials has been substantial. Pizotifen lessened the pruritus in six out of nine patients. Concentrations of conjugated bile acids were not related to the pruritus; the pruritic potential of iron deficiency in polycythaemia vera could not be separated from suboptimal disease control as judged by Coulter values.
Pruritus is often a severe and at times intractable symptom in polycythaemia vera; we found pizotifen to be an effective antipruritic agent. The mechanism of action is uncertain. In those patients who failed to respond it might have been valuable to increase the dose and prolong treatment, for in migraine prophylaxis a beneficial effect is seldom immediate and individual tailoring of dosage is often required. ${ }^{5}$

${ }^{1}$ Vickers CFH. Nutrition and the skin. In: Ledingham JGG, ed. Proceedings of the 10th symposium on advanced medicine. London: Royal College of Physicians, 1974:311-5.

${ }^{2}$ Chanarin I, Szur L. Relief of intractable pruritus in polycythaemia rubra vera with cholestyramine. Br $\mathcal{F}$ Haematol 1975;29:669-70.

${ }^{3}$ Gilbert HS, Warner RRP, Wasserman LR. A study of histamine in myeloproliferative disease. Blood 1966;28:795-806.

${ }^{4}$ Easton P, Galbraith PR. Cimetidine treatment of pruritus in polycythaemia vera. $N$ Engl f Med 1978;299:1134.

${ }^{5}$ Spreight TM, Avery GS. Pizotifen: a review of its pharmacological properties and therapeutic efficacy in vascular headaches. Drugs 1972; 3:159-203.

(Accepted 1 May 1981)

\section{Western Infirmary, Glasgow G11 6NT}

E J FITZSIMONS, BSC, MRCP, medical registrar (present appointment: lecturer in haematology, Welsh National School of Medicine, Cardiff CF4 4XW)

J H DAGG, MD, FRCP, consultant physician

E J MCALLISTER, BSC, DIPCB, senior biochemist

\section{Fatal bone-marrow suppression associated with captopril}

Reports of haematological toxicity ${ }^{1-4}$ and especially fatal pancytopenia ${ }^{5}$ associated with treatment with captopril prompted us to describe a case of fatal bone-marrow suppression associated with a combination of captopril and labetalol, an alpha-beta-blocker.

\section{Case report}

A 32-year-old woman was admitted in May 1980 for essential malignant hypertension with blood pressure of $220 / 130 \mathrm{~mm} \mathrm{Hg}$, retinal haemorrhages and cotton-wool exudates on fundoscopy, and creatinine clearance of $6 \mathrm{ml} / \mathrm{min}$. Sodium nitroprusside, acebutolol, propranolol, clonidine, labetalol, dihydrallazine, and frusemide were tried in varying combinations and dosages, but the severe hypertension persisted.

She was readmitted on 15 July to try new antihypertensive combinations. After making sure that there was no underlying disease or, especially, lupus erythematosus (lupus erythematosus phenomenon and anti-DNA antibodies were absent) and that blood count was nearly normal (red cell count $2800 \times$ $10^{9} / 1$, reticulocytes $84 \times 10^{9} / 1$, white cell count $4.6 \times 10^{9} / 1$, neutrophils $74 \%$, platelets $160 \times 10^{9} / \mathrm{l}$ ) we started a combination of captopril $100 \mathrm{mg} / \mathrm{day}$, acebutolol $1200 \mathrm{mg} /$ day, dihydrallazine $100 \mathrm{mg} /$ day, and frusemide $40 \mathrm{mg}$ / day. She was discharged on 30 August, when her blood pressure was well controlled $(140 / 60 \mathrm{~mm} \mathrm{Hg})$. Blood pressure subsequently increased to $200 / 120 \mathrm{~mm} \mathrm{Hg}$, and on 19 September we replaced acebutolol and dihydrallazine with labetalol $1200 \mathrm{mg}$ then $800 \mathrm{mg}$ a day. On 9 October blood pressure was $150 / 90 \mathrm{~mm} \mathrm{Hg}$, the fundus grade II, and creatinine clearance $12 \mathrm{ml} / \mathrm{min}$.

She remained well until 24 January 1981 , when she was readmitted because of hypotension and nose bleeding, which had started one week previously. Blood cell count showed packed cell volume $10 \%$, red blood cells $1000 \times 10^{9} / 1$, and white cell count $1.2 \times 10^{9} / 1$ (neutrophils $34 \%$ and platelets $\left.5 \times 10^{9} / 1\right)$. A bone-marrow aspirate showed reticular cells, bone cells, some lymphocytes, and many adipocytes but no erythropoietic and granulopoietic cell lines and no megaryocytes. Direct and indirect Coombs tests were negative. Because of the pancytopenia captopril was stopped on the first day of admission and labetalol 15 days later. Cell counts performed twice weekly over seven weeks showed no improvement, and she developed pneumonia. She was treated with antibiotics, packed red cells, and platelets. She did not improve so was admitted to a haematological intensive care unit. A bone-marrow graft was planned, but she died of septicemia on $20 \mathrm{March}$ - that is, eight weeks after the pancytopenia was discovered.

\section{Comment}

This is the second reported case of fatal pancytopenia associated with treatment with captopril. Eighteen cases of leukopenia, ${ }^{1-4}$ among them three of agranulocytosis, ${ }^{12}$ have been reported during the 